\title{
PROCESS OF MANAGEMENT OF AGRICULTURAL ENTERPRISES RESOURCES BASED ON THE ECONOMIC POTENTIAL OF BIOFUEL PRODUCTION
}

\section{ПРОЦЕС УПРАВЛІННЯ РЕСУРСАМИ АГРАРНИХ ПІДПРИЕМСТВ НА ОСНОВІ ЕКОНОМІЧНОГО ПОТЕНЦАЛУ ВИРОБНИЦТВА БІОПАЛИВА}

\section{Tatiana Korpaniuk ${ }^{1}$}

DOI: https://doi.org/10.30525/978-9934-588-53-2-6

Abstract. The research paper deals with the formation of new scientific decisions regarding the improvement of the processes of resource management of agrarian enterprises on the basis of economic diagnostics of biofuel consumption. In the course of the research, the essence of the research paper is revealed and the features of the use of tools of economic diagnostics in relation to a particular energy resource as the basis for substantiation of effective management decisions concerning resource management of a modern agricultural enterprise are described. The research methodology is based on the system approach, the identification of causal relationships (deduction, induction) and the synthesis of factors that influence the implementation of the development potential and improvement of resourcing for the operation of modern agricultural enterprises in Ukraine. The research paper systematically presents the processes of providing agricultural enterprise with fuel resources as an element of the resource management system, which focuses on the direction of biofuel consumption, its economic diagnostics, the identification of problems, prospects of use and developmental prerequisites. It is shown that structured integrated economic diagnostics of biofuel consumption by agricultural enterprises as part of a certain system, action algorithm, to a large extent positively influences on the success of application in practice of the tools of resource management of these enterprises, increasing the soundness of managerial

\footnotetext{
${ }^{1} \mathrm{PhD}$ in Economics, Associate Professor of Accounting and Taxation Department in Economics,

Vinnytsia National Agrarian University, Ukraine

(C) Tatiana Korpaniuk
} 
decisions in this area. This contributes to a more efficient organization of the processes of the agrarian enterprises of Ukraine, giving an opportunity to respond adequately to the variability of the market environment and create the preconditions for the long-term development.

The research objective is to formulate scientific solutions regarding the improvement of resource management processes of agricultural enterprises on the basis of economic diagnostics of biofuel consumption. The achievement of this objective involves revealing the essence and peculiarities of using the tools of economic diagnostics as the basis for substantiating managerial decisions that should be incorporated into the model of efficient resource management of agricultural enterprises that consume or plan to consume biofuels for their own industrial and organizational needs.

In general, the range of problems of increasing the efficiency of the resource base of agricultural enterprises is directly related to their activities as producers of agricultural products. The assimilation of new technologies, the development of organizational and economic conditions of the activity of enterprises under the influence of this technology, determine the possibility of increasing the efficiency of the enterprise. At the same time, these processes require constant analysis and monitoring; in this context, the economic diagnostics of biofuel consumption by agricultural enterprises is a topical direction of scientific research.

The novelty of the study is to consider the processes of providing agricultural enterprises with fuel resources as an element of the resource management system, which focuses on the direction of biofuel consumption, its economic diagnostics, identification of problems, prospects for the use of biofuels by agricultural enterprises and the preconditions for the development of resource supply through the expansion of biofuel use.

\section{1. Ветуп}

Динамічний розвиток глобальної економіки, що, зокрема позначається на розвитку транспортних перевезень, активному використанні енергетичних ресурсів, поряд з багатьма перевагами, також призводить до виникнення серйозних глобальних проблем, обумовлених збільшенням попиту на енергоносії в умовах виснаження природних невідновлювальних джерел енергії та поступової деградації навколишнього природного середовища (внаслідок надмірної експлуатації природ- 
них ресурсів та значних викидів парникових газів). В якості способу часткового вирішення даної проблеми значна кількість дослідників, зокрема $[1 ; 9 ; 42]$, розглядають розвиток сектора відновлюваної енергетики, включаючи сектор рідкого біопалива.

Концепція використання сировини сільськогосподарського походження для енергетичних цілей не є новою, вона має історію формування понад сто років, однак протягом більш ніж десяти останніх років спостерігається збільшення ролі відновлюваного палива, що відображається у збільшенні його виробництва та споживання. Це обумовлює важливість розгляду біопалива як важливого фактору формування сучасної енергетичної політики багатьох країн та аграрних секторів економіки цих країн, зокрема - аграрного сектору, де, власне, виробляються біоматеріали, що використовуються для виробництва біопалива, та $є$ можливість безпосереднього та активного використання отриманого біопалива для задоволення потреб аграрних підприємств у паливно-енергетичних ресурсах.

Отже, сучасні аграрні підприємства розвиваються, змінюються їх функції. На додаток до найважливішого завдання, яким є виробництвом продуктів харчування, промислових кормів, в даний час аграрні підприємства все більше розглядаються як виробник сировини для зростаючої галузі біопалива. Потенціал використання енергії аграрної продукції стосуються в основному рапсу, буряків та олійних рослин.

Зазначені процеси супроводжуються зростанням взаємозалежності між сектором виробництва рідкого біопалива та аграрними ринками, де реалізується продукція, яка може використовуватись у якості сировини для виробництва біопалива. 3 одного боку, можна передбачати, що виробництво та використання рідкого біопалива допоможе подолати проблеми забезпечення паливними ресурсами агровиробників та стане джерелом додаткових вигід від реалізації біопалива. 3 іншого боку, економічний потенціал виробництва біопалива з сировини сільськогосподарського походження та його подальшого споживання аграрними підприємствами може бути обмежений через негативний вплив на навколишнє середовище та вплив на повноцінність виконання традиційних функцій аграрних підприємств щодо забезпечення суспільства сільськогосподарською продукцією. 3 огляду на те, що, вбачаючи більший потенціал у енергетиці аграрні підприємства обме- 
жать розвиток основної діяльності, створюючи загрози стратегічно важливій продовольчій безпеці країни.

Вищезазначена проблематика обумовила потребу пошуку нових наукових рішень у напрямку створення ефективного інструментарію управління ресурсами аграрних підприємств на основі економічної діагностики споживання біопалива, визначення передумов удосконалення процесу управління ресурсами на цій основі.

Огляд літератури. Концепція сталого розвитку, в межах якої формуються на глобальному, регіональному стратегічному рівні передумови розвитку альтернативних джерел енергії, відновлювальної енергетики, сформувалася як осмислення нових соціально-економічних процесів «соціалізації» та «екологізації» умов функціонування сучасної економіки, як спроба вирішити протиріччя між феноменами «ефективна економіка» та «майбутнє нових поколінь», «соціальна відповідальність», «збереження біорізноманіття» [5; 10]. Дослідженню проблем сталого розвитку присвячені роботи [4; 44], в яких висвітлені питання становлення концепції сталого розвитку як ключової парадигми та траєкторії суспільно-економічного поступу.

Тривають дискусії й щодо ролі держави в процесі забезпечення умов сталого розвитку підприємств [3; 6; 25], обгрунтованості заходів державного регулювання і формування балансу втручання держави в ринкові процеси.

Слід відзначити роботи в яких здійснено порівняльний аналіз вирішення конкретних проблем сталого розвитку в країнах, що розвиваються $[18 ; 29 ; 41]$. Дані дослідження важливі для розуміння специфіки діяльності розвитку на макро- та мікрорівні в країнах колишнього СРСР, поряд з роботами, присвяченими відображенню успішного досвіду в країнах Східної Європи і країнах, що розвиваються [16; 24].

Водночас, дотепер не представлено повноцінного комплексного підходу до управління та оцінки потенціалу сталого розвитку на мікрорівні в конкретних напрямках, що можуть бути корисними для вирішення проблем сталого розвитку. Одним з таких напрямків є споживання аграрними підприємствами біопалива, що, певною мірою досліджується в роботах сучасних авторів, таких як [42; 45], але не містить ознак комплексності та суттєво обмежено використовують 
потенціал інструментарію економічної діагностики використання біопалива у практиці аграрних підприємств.

Питання розвитку сектору рідкого біопалива в глобальному масштабі та в окремих країнах розглядаються в дослідницькому середовищі [9; 22; 42], але в значній мірі, особливо у Сполучених Штатах та країнах $\mathrm{CC}$, ці роботи найчастіше фокусуються на визначенні можливого впливу виробництва рідкого біопалива на вартість сільськогосподарської сировини, а також на проблемах саме виробництва, а не споживання біопалива аграрними підприємствами.

На думку автора статті, розглядаючи споживання біопалива як предмет оцінки, слід більш детально розглядати дослідницькі напрацювання та моделі стосовно інструментарію економічної діагностики певних процесів. У цьому контексті вітчизняна та зарубіжна наука сформувала певний науковий доробок стосовно проблематики та використання аграрними підприємствами інструментарію економічної діагностики. Так, проблеми економічної діагностики аграрних підприємств та іiі застосування в процесі визначення ефективності використання біопалива як джерела альтернативної енергетики, займаються В. Герасимчук, О. Гудзь, Г. Калетнік, О. Прутська, А. Самойленко, В. Савчук, 3. Соколовська, Г. Швиданенко.

Проблематиці інформаційно-аналітичного забезпечення економічної діагностики різних аспектів діяльності присвячені праці О. Правдюк, В. Зарубинського, Ю. Цал-Цалко, А. Щербака. У працях цих авторів грунтовно розкриваються основи здійснення економічної діагностики окремих сфер, напрямів діяльності, опрацьовано методичні підходи діагностики, наведено алгоритми розрахунку діагностичних показників тощо. Однак у наукових публікаціях не напрацювання не систематизовано в достатній мірі, щоб виокремити конкретне дослідження як комплексне та всебічне, не враховано також взаємозв'язки між різними елементами діагностики розвитку та діяльності конкретно аграрного підприємства, що споживає біопаливо або планує це.

Отже, вивчення і узагальнення наукових праць вчених-економістів показало, що ще недостатньо дослідженими, але такими, що є актуальними та активно розробляються, залишаються аспекти, пов'язані зі специфікою функціонування аграрних підприємств в умовах необхідності підвищення ефективності їх ресурсного забезпечення, де спо- 
живання біопалива виступає важливим фактором забезпечення ресурсної незалежності, автономності у виробничих процесах та мінімізації витрат діяльності через використання відходів виробництва та незадіяних у виробництві основної аграрної продукції посівних площ.

\section{2. Методи та матеріали}

Методологія дослідження базується на системному підході та узагальнені факторів, що впливають на реалізацію потенціалу розвитку аграрних підприємств, що використовують біопаливо у своїй поточній виробничій діяльності. Методологічними засобами, що логічно продовжують системний підхід, є синергетичний підхід і принцип коеволюції. Синергетичний підхід грунтується на теорії самоорганізації і передбачає комплексний облік зв'язків різних рівнів і форм між елементами системи, розвиток яких зміцнює ії цілісність і ефективність, робить можливим виникнення нової якості. Застосування принципу коеволюції в даному дослідженні можна конкретизувати в контексті єдності і взаємодії природного, економічного і соціального в процесі досягнення цілей розвитку.

В роботі процес управління ресурсами аграрного підприємства, елементом якого $є$ споживання біопалива, представляється як комплекс елементів і властивостей, взаємодія між якими формує нові передумови підвищення ефективності і використання ресурсів аграрними підприємствами.

Дослідження також базується на віднесенні біопалива за технологічними принципами до однієї з трьох груп [23]:

1) Біопаливо першого покоління потребує значної кількості орних земель або переведення частки харчових продуктів рослинництва в сировину, що призводить до серйозної нестачі продовольства. Так, для виробництва енергокультур у 2008 році було використано $2 \%$ загального світового фонду орних земель, що дорівнює 36 млн. га. В цілому ж можна констатувати, що виробництво біопалива першого типу негативно впливає на глобальний ринок сільськогосподарської продукції.

2) Біопаливо другого покоління виробляється з біомаси (нехарчові частини рослини, нехарчові рослини та виробниче сміття). Вже сьогодні, на території більшості країнах Євросоюзу діє заборона складуванню відходів 3 калорійністю більше 6 Мдж/кг, оскільки вони можуть 
бути сировиною для альтернативних видів палива і утилізуватися термічно. Тому виникає потреба у пошуку нових, альтернативних методів повторного використання відходів. На даний час, біопаливо другого покоління, використовується обмежено через значну витрату енергії та дороговизну технологій, отже, має обмежені перспективи розвитку.

3) Біопаливо третього покоління є найбільш перспективним. Це - біопаливо із водоростей, яке забезпечить виробництво екологічно чистого бензину без використання сільськогосподарських земель та без застосування прісної води, мінеральних добрив та засобів захисту рослин із стабільною продуктивністю до 100 т/га в рік. Паливо із життєдіяльності спеціальних бактерій (геномодифіковані організми, здатні споживати рослинні рештки виробляючи насичені вуглеводні (алкани), які є основою бензину) при масовому виробництві може стати гідною заміною бензину, вартість якого не перевищуватиме 50 доларів за барель. Розробки виробництва палива третього покоління знаходяться поки що на стадії дослідження і не мають широкого розповсюдження.

У даній статті, передусім мова йде про використання аграрними підприємствами України біопалива другого покоління, через нерозвиненість виробництва біопалива третього покоління та негативний вплив біопалива третього покоління на агровиробництво.

\section{3. Основний зміст статті}

Традиційні методи управління ресурсами аграрних підприємств України недостатньо ефективні в швидкоплинному високо конкурентному бізнес-середовищі. Сталий розвиток підприємств передбачає узгодження короткострокових цілей і інтересів різних груп і окремих індивідів в складі підприємства 3 довгостроковими стратегічними цілями, обумовленими вимогами його розвитку та наявними ресурсними можливостями. У зв'язку з цим управління ресурсами аграрного підприємства - важлива умова ефективності діяльності вітчизняних аграрних підприємств. Саме тому, одним з актуальних питань економічних досліджень $є$ пошук шляхів забезпечення адекватного новим умовам господарювання процесу управління ресурсами вітчизняних аграрних підприємств.

Сучасний стан забезпечення сталого розвитку аграрних підприємств України характеризують наступні проблеми (рис. 1). 
Проблеми управління ресурсами та забезпечення умов сталого розвитку аграрних підприємств України

розвиток аграрних підприємств в Україні є здебільшого неформалізованим процесом, який залежить від багатьох факторів, не існує нормативів та чітких критеріїв, на основі яких можна було б отримати висновок про вплив цих факторів на сталість розвитку підприємств

недостатність систематизованої інформації про діяльність підприємства та вплив на неї зовнішнього ринкового середовища для формування інструментарію та, особливо, стратегії розвитку вітчизняних аграрних підприємств

завдання, які повинні бути вирішені за допомогою підвищення ефективності використання ресурсів аграрних підприємств України не встановлені або сформульовані в поняттях, які не пов'язані зі сталим розвитком та управлінням ресурсами як окремим напрямом менеджменту

впровадження інструментарію управління ресурсами українських аграрних підприємств відбувається без достатнього попереднього науково-дослідницького обгрунтування

недостатність матеріальних і фінансових ресурсів для активізації інструментарію управління ресурсами та забезпечення умов сталого розвитку аграрних підприємств України

\section{Рис. 1. Проблеми управління ресурсами та забезпечення умов сталого розвитку аграрних підприємств України}

Джерело: розроблено автором

Очевидною є необхідність забезпечення повноцінної оцінки потенціалу певних напрямків удосконалення використання ресурсів чи ресурсного забезпечення, як інформаційної основи для обгрунтування інструментарію управління ресурсами аграрних підприємств.

В якості цілей такої оцінки доцільно виділити виявлення передумов забезпечення завдяки використанню певних видів ресурсів:

- більш високої фінансово-економічної ефективності функціонування підприємств, їх фінансової стійкості підприємства;

- більшої технологічної відповідності виробничих процесів сучасним вимогам та новітнім можливостям;

- більшої конкурентоспроможності підприємств та їх продукції;

- більш високої ефективності реалізації виробничих процесів; 
- більш повного задоволення соціальних потреб працівників підприємства та громадян країни;

- більш повноцінного забезпечення безпечних екологічних умов діяльності співробітників підприємств та мінімізації руйнівного впливу наслідків виробничо-господарської діяльності на екологію.

Таким чином, одним 3 найважливіших аспектів удосконалення управління ресурсами аграрних підприємств $є$ оцінка потенціалу певних напрямків споживання ресурсів, зокрема, відповідно до цілей даної статті - напрямку споживання біопалива. Дана оцінка в межах комплексу заходів економічної діагностики споживання підприємством біопалива, повинна відрізнятися цілеспрямованістю та комплексністю підходів, а також системністю та ефективністю застосовуваного аналітичного інструментарію.

У результаті повинен бути оцінений можливий економічний ефект від використання існуючих можливостей розвитку і конкурентоспроможності аграрного підприємства завдяки використанню в його діяльності біопалива як виробничого ресурсу, що можливо при забезпеченні принципів комплексності, системності, оптимальності та об'єктивності в процесі здійснення економічної діагностики.

Інформаційно-аналітичне забезпечення економічної діагностики споживання біопалива аграрними підприємствами також тісно переплітається з вирішенням проблем обліку, статистики та звітності [13; 40]. Виробничі процеси та їх наслідки зображені у статистичній, фінансовій, податковій звітності та бухгалтерському обліку (П(С)БО 1). Для ухвалення управлінських заходів користувачам звітності необхідні точні дані про фінансово-економічний контур та його коливання й зміни, наслідки виробничої діяльності тощо. Ці потреби зумовили склад звітності підприємств, зокрема баланс, звіт про рух грошових коштів, звіт про фінансові результати, звіт про власний капітал, різноманітні примітки до звітів. Інформаційний масив має надати достатню об’єктивну та легку у використанні інформацію щодо фінансово-економічного контуру підприємства, інтенсивності, ритмічності руху його фінансових потоків, коливань параметрів капіталу та його структури тощо.

Якість інформаційно-аналітичного забезпечення економічної діагностики споживання біопалива аграрними підприємствами вимірю- 
ється можливістю ранньої превенції та корегування виявлених загроз. Вади у побудові композиції інформаційно-аналітичного забезпечення можуть мати наслідком неочікувані деформації та кризові прояви, оскільки інформаційний масив $\epsilon$ платформою здійснення економічної діагностики загроз, прогнозування їх впливу, визначення ефективності ухвалених стратегічних заходів тощо [21; 40].

Рівень енергозалежності України є середньоєвропейським. Лише на 53\% забезпечується потреба в паливно-енергетичних ресурсах. Енергодефіцитність економіки зумовлена насамперед імпортом природного газу (75\%) та нафтопродуктів (85\%).

Аграрне виробництво споживає 35 млн. т умовного палива за рік, поступаючись за рівнем споживання енергії у економіці України лише чорній металургії (50 млн. т умовного палива за рік). Підвищення цін на енергоносії та висока частка енергії у вартості продукту, впливають на конкурентоздатність виробленої ними продукції на світовому рівні. Це зумовлює необхідність застосування альтернативних джерел енергії. Серед яких вагоме місце посідає біопаливо [19].

За даними Державного агентства 3 енергоефективності та енергозбереження України, станом на перше вересня 2013 року потужність об’єктів відновлювальної енергетики становить 956,2 МВт, 3 яких 310,5 МВт - введено в експлуатацію в поточному році. Це дозволило зекономити більше 5,7 млрд.м ${ }^{3}$ природного газу.

В Україні, з метою стимулювання виробництва біопалива застосовуються коефіцієнти «зелених» тарифів для електроенергії з біомаси та біогазу, що дорівнюють 2,30 та поступово знижуватимуться до 1,61 в 2025 році. За рахунок енергозбереження, згідно висновків експертів, Україна до 2020 року може зменшити витрати на імпорт енергоресурсів близько 38 млрд. дол.(еквівалентна 470 млн. т. умовного палива).

Дослідження міжнародного досвіду енергозбереження вказують на застосування різних підходів до реалізації енергетичної політики. Водночас, основою екологічної стратегії більшості країн світу є підтримка технологічно-інноваційної діяльності, фінансуються розробка проектів та дослідження у сфері екології та охороні здоров'я. Посилення вимог екологічних стандартів та зростання ціни пального спонукають індустрію розвинутих країн переорієнтуватись на інноваційно-економічний режим виробництва. А отже, новітні екологічні стратегії при- 
зводять до кардинальних змін, реформування та реструктурування національних виробництв [19].

На нашу думку, більш ефективніше дані заходи здійснюються у країнах Європейського Союзу. Так, основними документами «нової енергетичної політики СС», що визначили загальні правила функціонування внутрішнього ринку електроенергії і газу, стали Енергетична Хартія та Договір до Енергетичної Хартії. Директиви 2003/55/ЕС і 2003/54/ЕС окреслили принципи функціонування ринку, які забезпечували б вільну конкуренцію, розвиток компаній і інтереси споживачів. Необхідно відзначити, що рівень енергозабезпеченності власними енергетичними ресурсами у країнах ЄС суттєво різниться, створюючи значні перешкоди у формуванні єдиних цін, а отже і вільної конкуренції. Так, наприклад в Естонії громадяни сплачують за 1 тис. куб. м. спожитого газу 195 євро, а в Німеччині - 545 євро [35].

Ключова роль у екологічній стратегії ЄС відведена програмі переходу на альтернативні та поновлювальні джерела енергії, серед яких значна увага приділяється біопаливу. Директивою з відновлювальної енергетики 2009 року Європейська комісія зобов'язала підвищити частку відновлювальних джерел енергії європейських держав до 2020 року до рівня 10\%. При чому біопаливо має особливі вимоги: частка викидів вуглекислого газу при його використанні повинна бути мінімум на $35 \%$ меншою ніж у бензині (передбачається зростання межі до $60 \%$ у 2018 році). Але пріоритетність виробництва біопалива може спричинити дисбаланс у природному середовищі і загрожуватиме продовольчій безпеці. Тому не виключений перегляд та доповнення стратегії новими орієнтирами. За новою схемою торгівлі квотами на викиди передбачається поступова втрата права на безкоштовні квоти енерговиробниками і застосування механізму аукціонів у їх придбанні.

У контексті забезпечення потреб сталого соціо-еколого-економічного розвитку через використання потенціалу відновлювальної енергетики слід відзначити, що на даний час не існує жодного відомого джерела енергії, який був би повністю збалансованим [1; 45]. Звісно ж, поновлювані джерела енергії в значній мірі відповідають вимогам збалансованості: вони не виснажують обмежені природні ресурси, їх використання пов'язане зі значно меншим негативним впливом на навколишнє середовище, ніж використання нафти, газу, вугілля, та 
є в цілому соціально, економічно та екологічно прийнятним. Проте деякі з них мають серйозні проблеми. Наприклад, енергія вітру, що $\epsilon$ повністю поновлюваним джерелом, не гарантує стабільності енергопостачання. 3 іншого боку, біомаса (зернові, олійні, енергетичних культур для виробництва біопалива) $є$ джерелом природних і поновлюваних джерел.

Виробництво біопалива чинить позитивний вплив на розвиток сільського господарства і збільшення доходів сільськогосподарських підприємств (формуючи додатковий попит на сировину), але, водночас, сам процес виробництва потребує істотних витрат енергії (безпосередньо - у зв'язку з виробництвом сировини та їі переробкою, побічно - в зв'язку з виробництвом добрив, засобів захисту рослин, що використовуються як сировина, їх транспортуванням). Очевидно, що з цими процесами пов'язані викиди забруднюючих речовин в атмосферу.

Серед проблем виробництва та споживання біопалива - необхідність збільшення посівної площі для енергетичних культур (в основному зернових, олійних), що виражається в зменшенні біорізноманіття та може привести до деградації грунту, або завищеного споживання води і енергії у процесі виробництва сільськогосподарської сировини. 3 цієї причини було б доцільно розглянути баланс вигід та збитків від використання біопалива аграрними підприємствами. Виходячи з мети та теми даної роботи даний баланс передусім буде розглядатись в контексті економічного розвитку аграрних підприємств, водночас аспекти соціально-екологічного розвитку також повинні враховуватись, тому що в сучасному світі вони чинять (передусім через регуляторну політику та систему суспільного та державного контролю та нагляду) значний вплив на економічну ефективність підприємств та успішність реалізації економічних цілей розвитку. Також важливо зосередитись на проблематиці споживання біопалива аграрними підприємствами, що певною мірою звужує дослідницьке поле та орієнтує на формування передумов покращення ресурсного забезпечення, і вже в іншу чергу - отримання прибутків від виробництва біопалива.

Провідними спеціалістами, на основі наукових досліджень було виявлено, що біопаливо, в залежності від багатьох чинників, може здійснювати як негативний, так і позитивний вплив на навколишнє середовище. Ще в березні 2011 року Швейцарією, під час круглого 
столу з питань сталого біопалива, було запропоновано показові параметри для системи сертифікації біопалива, які чітко розмежовують види на екологічно небезпечні та необхідні. Різні підходи в питанні виміру впливу біопалива на навколишнє середовище провокують ряд спірних питань. При цьому вплив виробництва може радикально різнитись в залежності від виду біомаси, об'єму, територіального розміщення і та ін. [19].

Вирощування цукрового очерету в центральних регіонах Бразилії для виробництва етанолу спричинило локальне охолодження на 0,930 . Дане регіональне охолодження зменшує вплив підвищеної продуктивності сільського господарства на землекористування в посушливих регіонах . При чому, використання макухи при виробництві етанолу 3 цукрової тростини, забезпечує електроенергією сам процес виробництва.

Виробництво біопалива 3 пальмової олії може зменшити шкідливі викиди на 80\%, проте, якщо виробництво спричинить вирубку тропічних лісів, то парниковий ефект зросте на 800\% і більше, а якщо для виробництва будуть знищуватись торф'яні ліса - то на 2000\% у порівняні з викопними видами палива [19].

Використання біоетанолу з кукурудзи може зменшити до 60\% викидів вуглекислого газу. Але якщо при виробництві та переробці даного виду палива використовуватимуться викопні види палива, то викиди парникових газів збільшаться до 5\%.

В Україні, процес екологізації економіки має два виміри - «формування нових «зелених галузей» економіки» та «екологічна модернізація». Особлива увага приділяється проблемам енергетичного сектору економіки, зокрема енергетичній безпеці. Висока енергоємність економіки та нераціональне енергоспоживання знижують конкурентоспроможність продукції, що створює навантаження на зовнішньоторговельний баланс та посилює економічну, політичну та енергетичну залежність нашої держави.

Виробничо-фінансова діяльність та їх наслідки відображені у інформаційних потоках. Інформаційний масив у фінансово-економічній сфері підприємства є неоднорідним: моделі його взаємозв'язків, взаємозалежність його видів різняться інтенсивністю, ритмічністю надходження, складністю опрацювання [8]. Тому разом із систематич- 
ним помітним збільшенням інформаційних потоків відчувається брак необхідних даних для ухвалення адекватних управлінських заходів. Це визначає його надмірність і унеможливлює повноту опрацювання даних $[11 ; 21]$. Проблема полягає у тому, щоб із наявного інформаційного масиву відфільтрувати такі дані, які б були мінімальними за кількістю та були достатніми для прийняття рішень [11; 46].

Економічна діагностика споживання біопалива аграрними підприємствами сприятиме своєчасному розпізнанню та ідентифікації стану підприємства за латентними непрямими проявами, що $є$ особливо необхідним за сценарієм змінності та дисбалансування економічного простору.

Метою економічної діагностики споживання біопалива аграрним підприємством можна вважати інформаційно-аналітичне забезпечення ухвалення управлінських рішень стосовно управління ресурсами на базі аналізу потенціалу підприємства отримувати вигоди від використання у якості енергетичного ресурсу біопалива, а також демаскування слабких сторін чи потенційних можливостей удосконалення ресурсного забезпечення діяльності підприємства.

Хоча нині ще не сформовано єдиної концепції розгляду змістового наповнення фінансово-економічної діагностики підприємства, проте можна простежити поглиблення ii ролі та розширення іiі функцій в системі корегування діяльності підприємства [15; 31; 32], водночас, виокремлення певного напрямку економічної діагностики в межах вирішення завдань управління ресурсами підприємства не здійснено дотепер.

Слід відзначити, що послідовно реалізований процес економічної діагностики споживання біопалива на рівні конкретного аграрного підприємства, як комплексне економічне дослідження, є складовою частиною механізму управління ресурсами даного підприємства, яке визначає, зокрема, який тип конкурентної боротьби - оборонний чи наступальний - доцільно використовувати у найближчій перспективі.

Так, за переконанням [33], проведення економічної діагностики потребує використання певної сукупності інформації внутрішнього та зовнішнього характеру стосовно результатів та перспектив економічної діяльності підприємства, його фінансово-майнового становища. Можливість формування та якісні ознаки інформаційної бази дослідження визнаються вагомими чинниками, оскільки доступ до певних 
джерел інформації зумовлює повноту та достовірність інформації, вибір методів дослідження, коректність діагностичного висновку [33].

Набір діагностичних показників не має бути широким, оскільки це значно ускладнить розрахунки, збільшить час проведення діагностики, спричинить наявність математичної погрішності, а отже, до викривлених висновків. Інша проблема стосується пошуку необхідної об'єктивної економічної інформації [47].

Відібрані для фінансово-економічної діагностики споживання біопалива аграрними підприємствами індикатори та показники повинні відповідати наступним вимогам:

- бути достовірними та детальними, тобто правдиво і детально відображати реальні результати економічної діяльності аграрних підприємств, пов'язаної з використанням біопалива;

- бути специфічними, тобто відображати специфіку діяльності аграрних підприємств та специфіку споживання біопалива як енергетичного ресурсу саме в аграрній сфері;

- бути масштабними, тобто характеризувати всі істотні функціональні напрями, проблеми, можливості та перспективи споживання біопалива аграрними підприємствами;

- бути порівняними, тобто узятими за один і той же період часу.

В процесі економічної діагностики споживання біопалива аграрними підприємствами особливу увагу слід звернути на коливання показників у часі.

Економічна діагностика споживання аграрним підприємством біопалива, на думку автора даної статті, містить наступні ключові оціночні блоки:

1) діагностика за «слабкими сигналами», що надходять до підприємства, в межах якої проводиться попередня термінова кількісна і якісна експертиза циклу кругообігу ресурсів на підприємстві як на визначений момент часу (статична), так і за визначений проміжок часу (динамічна) та попередне визначення поточного місця та потенціалу біопалива у ресурсному забезпеченні підприємства;

2) поглиблена діагностика за ключовими напрямками діяльності. В межах комплексу заходів економічної діагностики за даним етапом:

- кількісно в статиці і в динаміці оцінюються параметри деформацій та порушення пропорцій у фазах циклу кругообігу ресурсів та капі- 
талу аграрних підприємств при використанні поточної моделі забезпечення ресурсами та при застосуванні моделі, заснованої на споживанні біопалива. Порівняння результатів оцінки за даними моделями;

- виявляються причини деформацій, викривлень й порушення пропорцій у фазах циклу кругообігу ресурсів аграрних підприємств, динаміка зміни їх впливу при реалізації конкретних варіантів використання біопалива як енергетичного ресурсу на перебіг вирішення проблем функціонування та розвитку підприємства;

3) виявлення можливостей поглиблення та способів вирішення економічних проблем аграрного підприємства за рахунок використання біопалива у виробничо-господарській діяльності;

4) узагальнення результатів економічної діагностики споживання біопалива та їх впливу на діяльність(стан, розвиток, стійкість функціонування) аграрного підприємства.

У публікаціях щодо проблем економічної діагностики управлінських заходів показано низку показників та коефіцієнтів, які, у залежності від мети та завдань здійснення діагностики, об'єднані за певними кластерами. Аналітичні підходи до окреслення фінансово-економічного контуру підприємства, які широко застосовувалися в попередні періоди, можуть бути враховані і сьогодні для характеристики економічного стану підприємства. Але значним недоліком такого розгляду $€$ те, що визначення відповідності й відхилення від заданих планових параметрів не дає можливості встановити, чому певні показники мають відхилення та за допомогою чого можна досягти бажаного результату $[11 ; 21 ; 36 ; 40]$.

На сьогодні у сільськогосподарських підприємствах широко застосовується ідентифікація економічного стану з урахуванням аспектів: композиції балансу, капіталу та платоспроможності. Більшість методичних підходів передбачають застосування різноманітних ідентифікаторів, що зображають різні аспекти фінансової та виробничої діяльності підприємства. Водночас чим ширший спектр ідентифікаторів застосовується, тим більш суперечливим може бути сформований висновок.

Інструментарій економічної діагностики споживання біопалива аграрними підприємствами має бути орієнтованим на визначення можливостей досягнення конкретних цілей сталого розвитку шляхом характеристики конкретних факторів на основі використання 
певних ресурсів або потенціалів. Такими факторами є: сфера діяльності аграрного підприємства; масштаб підприємства (мале, середнє, велике); стадії життєвого циклу; умови внутрішнього і зовнішнього середовища; місія і сформульовані цілі розвитку підприємства; обрані стратегії розвитку; способи оцінки; залучення зовнішніх (внутрішніх) консультантів; особисті якості керівника і його пріоритети і т.п.

Таким чином, модель механізму економічної діагностики споживання біопалива аграрними підприємствами передбачає врахування впливу факторів внутрішнього і зовнішнього середовища на діяльність вітчизняних підприємств і дозволяє не тільки оцінити потенціал використання біопалива як виду ресурсів, а й чітко окреслює проблемні сфери та напрямки можливого підвищення загального рівня розвитку на основі вибору варіанту розвитку ресурсного забезпечення. В результаті оцінки аналізуються відхилення від бажаного, цільового стану, формулюється перелік заходів, спрямованих на мінімізацію або усунення ризиків розвитку, пропонується і розробляється відповідна стратегія ресурсного забезпечення.

Механізм економічної діагностики споживання біопалива аграрними підприємствами являє собою систему цілей, принципів, критеріїв (кількісний аналог цілей) та показників, що дозволяють охарактеризувати кількісно та якісно фактори впливу (елементи об'єкта управління та їх зв’язки, на які здійснюється вплив для досягнення поставлених цілей) на можливість реалізації потенціалу використання біопалива у виробничо-господарській діяльності аграрних підприємств. Це можливо шляхом використання певної методичної бази:

- методів оцінки;

- ресурсів, які використовуються для оцінки (матеріальні і фінансові, використання яких реалізує обраний метод управління та забезпечує досягнення поставлених оціночних цілей).

Якісно реалізована економічна діагностика споживання біопалива аграрними підприємствами України створює необхідне аналітичне підгрунтя для формування антикризової програми даних підприємств, визначення типу стратегії конкурентної боротьби (оборонного, імітаційного чи наступального), переліку раціональних заходів для їх розвитку, а отже є складовою частиною системи попередження загроз і запорукою успішного розв'язання стратегічних цілей сталого розвитку. 
Концепція сталого розвитку є провідним принципом для людства протягом більш ніж двох десятиліть і з часом розширюється у нові сфери соціально-економічного життя. До певної міри це також стосується енергетичного сектору, включаючи сектор відновлюваної енергетики. Хоча відомо і широко прийнято ті вимоги, за яких використання біопалива також повинне вписатись у цю концепцію (і ідею сталого розвитку сільського господарства), на практиці в цій сфері спостерігаються певні проблеми.

Концепція сталого розвитку підтримує, серед іншого, думку щодо того, що біопаливо належить до поновлюваних джерел енергії, є біологічно розкладеним і безпечним для навколишнього середовища, що дозволяє обмежити залежність від нафтових ресурсів, а також створити додаткове джерело попиту на продукцію сільськогосподарського походження та відходи, що може підвищити доходи аграрних підприємств та сприяти розвитку сільського господарства і сільських районів. У свою чергу, є обмеження стосовно такого, оптимістичного погляду на споживання біопалива, пов'язані насамперед із сумнівною і дискусійною ситуацією щодо скорочення викидів парникових газів, а також необхідністю постійно збільшувати посівні площі сільськогосподарських культур в енергетичних цілях для реалізації цілей енергетики. Що стосується економічного аспекту, найбільш важливою проблемою $\epsilon$ несприятливий вплив виробництва біопалива на вартість сільськогосподарської продукції і продукти харчування [9; 22; 42]. Визначені проблеми - це обмеження, які не передбачають повноцінне виконання цілей сталого розвитку енергетики та аграрного сектору.

Представлене в статті дослідження в значній мірі перекликається 3 засадами «Нової теорії зростання», розробленої в 1980-х рр. Американським економістом Полом Ромером («Endogeous Technological Change» [30]), що передбачає ендогенну природу технологічного розвитку. Ключова цінність статті - спроба оцінки потенціалу споживання аграрним підприємством біопалива в рамках певної системи, алгоритму дій, втілених у вигляді структурованого механізму економічної діагностики споживання біопалива аграрними підприємствами України, застосування якого, в свою чергу, в певній мірі впливає на формування інструментарію управління ресурсами цих підприємств. У зв'язку з цим можна виділити деякі обмеження у застосуванні результатів даної статті, а 
саме - інструменти управління ресурсами, які доцільно застосовувати при тому чи іншому результаті економічної діагностики споживання біопалива аграрними підприємствами України можуть бути досить різними, тому стаття має характер більш абстрагований та потребує подальшої деталізації інструментарію управління та оцінки. У той же час, дане обмеження не знижує науково-практичної цінності даної статті і характеризує більшою мірою перспективи подальшого розвитку наукових результатів, отриманих автором.

\section{4. Висновки}

Економічна діагностика споживання біопалива аграрними підприємствами орієнтована на ухвалення гармонійних та дієвих управлінських заходів в межах процесу управління ресурсами, на підставі зібраного інформаційного масиву й оброблених аналітичних даних, які підлягають ранжуванню та сприяють ідентифікації фінансово-економічного стану, розробці рекомендацій щодо превенції чи усунення «проблемних аспектів». Крім того, економічну діагностику споживання біопалива аграрними підприємствами можна розглядати як дієвий інструмент інформаційної підтримки ухвалення управлінських заходів щодо корекції фінансово-економічного стану та ресурсного забезпечення, оскільки він, унаслідок його вагомого впливу на всю господарську діяльність підприємства, потребує своєчасного контролінгу, корекції та прогнозування.

Структурована економічна діагностика споживання біопалива аграрними підприємствами в рамках певної системи, алгоритму дій, втілених у вигляді механізму оцінки, в значній мірі позитивно впливає на успішність застосування на практиці інструментарію управління ресурсами аграрних підприємств. Визначено, що формування механізму економічної діагностики споживання біопалива аграрними підприємствами сприяє більш ефективній організації процесів забезпечення розвитку підприємства в сучасних умовах господарювання, зумовлюючи можливість адекватно реагувати на мінливість ринкового середовища та створювати передумови для довгострокового сталого розвитку.

Створення і реалізація механізму економічної діагностики споживання біопалива аграрними підприємствами сприяє формуванню напрямків, які б дали можливість реалізувати ефективні, дієві заходи 
забезпечення відтворення потенціалу сталого розвитку підприємства, оскільки саме приховані невикористані потенційні можливості зумовлюють можливість адекватно зреагувати на мінливість середовища та сформувати пріоритети розвитку. Ця особливість зумовлює потребу в розробці заходів щодо забезпечення потенціалу сталого розвитку аграрного підприємства в рамках стратегії сталого розвитку, постійної діагностики його складових частин, контролю і прогнозування, які повинні грунтуватися на комплексному підході.

Користувачами економічної діагностики споживання біопалива аграрними підприємствами можуть бути різні економічні суб'єкти, яким необхідна правдива та об'єктивна інформація щодо стану ресурсного забезпечення аграрного підприємства та визначення різноманітних загроз та ризиків його діяльності. Це, насамперед, власники, орендодавці, менеджери, працівники підприємства, тобто особи, що зацікавлені в успішності функціонування підприємства, ефективності управління його ресурсами. Також, потенційними користувачами результатів економічної діагностики споживання біопалива аграрними підприємствами є банки, які, у разі надання кредитів підприємствам, можуть застосовувати іiі для визначення можливостей своєчасного повернення кредиту та сплати відсотків.

Запропонована схема реалізації механізму економічної діагностики споживання біопалива аграрними підприємствами сприяє формуванню якісного об'єктивного інформаційного масиву та його структуруванню. Це дозволяє своєчасно отримувати інформацію стосовно загроз ресурсного забезпечення підприємства та формування якісної основи покращення системи управління ресурсами підприємства.

Практичне впровадження пропозицій і висновків даної статті слід розглядати в контексті їх важливості для стимулювання розвитку аграрних підприємств України в сучасних умовах, що потребує формування певної форми взаємодії суб'єктів економіки в рамках парадигми та принципів «сталого розвитку».

Перспективи подальших досліджень на основі і з використанням наукових результатів даного дослідження, складаються в аналізі, структуризації і формалізації моделей та збалансованої системи показників економічної діагностики використання біопалива та інших ключових енергетичних ресурсів у діяльності аграрними підприємствами. 


\section{Список літератури.}

1. Abbot, P. Biofuel, Binding Constrains and Agricultural Commodity Volatility, NBER Working Paper, 18873, 2013, pp. 1-46.

2. Allen, D. and Berg, C. The sharing economy: How regulation could destroy an economic revolution, Institute of Public Affairs. 2014. Retrieved from: http:www. ipa.org.au

3. Артемов А., Брыкин А., Шумаев В. Модернизация государственного управления экономикой. Экономист. 2008. № 2. С. 3-14.

4. Barua, P., Fransen, T. and Wood, D. Climate Policy Implementation Tracking Framework. Working 5 Paper. Washington, DC: World Resources Institute. 2014. Retrieved from: http://wri.org/publication/climate6policy-tracking

5. Бастиа Ф. Экономические гармонии. Избранное. Москва : Эксмо, 2017.

6. Bastow S. Governance, Performance, and Capacity Stress: The Chronic Case of Prison Crowding. Basingstoke: Palgrave Macmillan, 2013.

7. Carpenter D., Moss D. Preventing Regulatory Capture: Special Interest Influence and How to Limit It. New York: Cambridge University Press, 2014.

8. Чупис А. Финансовое положение предприятия (оценка, анализ, планирование) : [научно-методическое издание]. Сумы : Университетская книга, 1999.

9. de Gorter, H., Drabik, D. and Just, D.R. Biofuel Policies and Food Grain Commodity Prices 2006-2012: All Boom and No Bust? AgBioForum, 2013, vol. 16(1), pp. 1-13.

10. Fiore, E., and Tamborrini, P. Open System in bean cultivation for Local Economical Development. Scientific Conference proceedings, Zilina (Slovakia), 2014, 9-13 June, pp. 359-364.

11. Герасим П., Журавель Г., Хомин П. Курс управлінського обліку. Київ : Знання, 2007.

12. Herasymchuk V.H. Diahnostyka systemy upravlinnia pidpryiemstvom. Київ : ISDO, 1995.

13. Гудзь О. Методичні підходи щодо здійснення фінансової діагностики в агроформуваннях. Збірник наукових пращь Черкаського державного технологічного університету. Серія «Економічні науки» : у 3 ч. Черкаси : ЧДТУ, 2009, № 23. Ч. 1, с. 9-14.

14. Ходаківська О.В. Екологічна парадигма - основа розвитку господарських систем,Фізична економія у вимірах теорї $i$ практики господарювання: колективна монографія / За ред. Ю.О. Лупенка, В.М. Жука, В.О. Шевчука та О.В. Ходаківської. Київ : ННЦ «Інститут аграрної економіки», 2013. C. 226-227.

15. Hudz O.Ie. Prohnozuvannia finansovoi stiikosti ta platospromozhnosti ahrarnykh pidpryiemstv. Zb. nauk. prats Umanskoho natsionalnoho universytetu sadivnytstva. Seriia «Ekonomichni nauky». 2012, 77. Ch. 2, pp. 119-125.

16. Imas L., Morra G. and Ray, R. (2009). The Roads to Results: Designing and Conducting Effective 35 Development Evaluations. World Bank Publication.

17. Kaletnik H.M. Vyrobnytstvo ta vykorystannia biopalyv. Vinnytsia : Konsol, 2015.

18. Kamel S. and Dahl C. The economics of hybrid power systems for sustainable desert agriculture in Egypt. Energy (2004, forthcoming). Elsevier, 2004. 
19. Корпанюк T.M. Фінансово-економічна діагностика аграрних підприємств 3 виробництва біопалива. Економіка. Фінанси. Менеджмент: актуальні питання науки і практики. 2016. № 12. С. 63-70.

20. Корпанюк Т.M. Інформаційно-аналітичне забезпечення фінансовоекономічної діагностики в сільськогосподарських підприємствах. Вісник Одеського начіонального університету. Серія : Економіка. 2016. Т. 21. Вип. 5. С. 83-86.

21. Малюга Н. Шляхи удосконалення оцінки в бухгалтерському обліку: теорія, практика, перспективи. Житомир : ЖІTI, 1998. 384 с.

22. McPhail, L.L. and Babcock, B.A. (2012). Impact of US biofuel policy on US corn and gasoline price variability, Energy, 37, issue 1, pp. 505-513.

23. Moschini, G., Cui, J. and Lapan, H. (2012). Economics of Biofuels: An Overview of Policies, Impacts and Prospects, Economics Publications, 96. Retrieved from: http://lib.dr.iastate.edu/econ las pubs/96

24. Nilsson, M., et al. (2016). Policy: Map the interactions between Sustainable Development Goals, Nature, 18. Retrieved from: http://www.nature.com/news/policy-map-the-interactions-between-sustainable-development19goals-1.20075

25. OECD (2012). Background Report for the OECD Strategy on Development, C(2012)61/REV1, OECD, Paris.

26. Oxford Business English Dictionary. Retrieved from: http://askoxford.com/ conciseoed/rating? view $=\mathrm{uk}$

27. Правдюк, Н. Тенденції розвитку фінансового обліку в агропромисловому виробництві : [монографія]. Київ : ННЦ «Інститут аграрної економіки», 2005.

28. Pruts'ka, O.O. Derzhavne reguljuvannja rozvytku rynku biopalyva v Ukrai'ni. Visnyk Zaporiz'kogo nacional'nogo universytetu. 2010, № 1(5), pp. 179-182.

29. Report of the International Ministerial Conference of Landlocked and Transit Developing Countries and Donor Countries and International Financial and Development Institutions on Transit Transport Cooperation, Almaty, Kazakhstan, 28 and 29 August 2003 (A/CONF.202/3), annex I.

30. Romer, Paul M. (1999). Endogenous Technological Change, Levine's Working Paper Archive, 2135.

31. Samoilenko, A.H. Otsinka potentsialu ahrarnoi syrovynnoi bazy dlia vyrobnytstva biopalyva. Ekonomika ta pidpryiemnytstvo : zb. nauk. prats molodykh uchenykh ta aspirantiv. 2009. № 22, pp. 177-184.

32. Savchuk V.P. Fynansovj menedzhment predpryyatyj: pry`kladne voprosu s analyzom delovux sytuacyj. Kyiv : Yzdatelskyj dom "Maksymum", 2001.

33. Скібіцький О.М. Антикризовий менеджмент. Київ : Центр учбової літератури, 2009.

34. Стратегія екологічної безпеки України у контексті міжнародного досвіду. Відділ інтеграції та стратегічного партнерства. 2008. URL: http://old.niss.gov.ua/Monitor/Juli08/21.htm

35. Шевченко В. Використання енергозберігаючих технологій в країнах ЄC: досвід для України. Аналітична записка, Національний інститут стратегічних досліджень. 2018. URL: http://www.niss.gov.ua/articles/262/ 
36. Щербак А. Перспективи використання рейтингових оцінок в інвестиційній діяльності підприємств. Економіка та управління підприємствами. 2008. № 5(83). C. 83-91.

37. Shvydanenko H.O. Suchasna tekhnolohiia diahnostyky finansovo-ekonomichnoi diialnosti pidpryiemstva: monohrafiia. Kyiv : KNEU, 2002.

38. Sokolovskaia Z.N. Dyahnostyka khoziaistvennykh sytuatsyi v deiatelnosty predpryiatyia: monohrafyia. Odessa : OTsNT; OKFA, 1995.

39. Srebotnjak, T., Polzin, C., Giljum, S., Herbert, S. and Lutter, S. Establishing Environmental Sustainability Thresholds and Indicators: Final report. Brussels: Ecologic Institute and SERI. 2010.

40. Цал-Цалко Ю. Фінансова звітність підприємства та їі аналіз. 2-ге вид., перероб. та доп. Житомир, 2001.

41. Thorne, S. and Raubenheimer, S. Sustainable Development (SD) appraisal of Clean Development Mechanism (CDM) projects - experiences from the SouthSouthNorth (SSN) project. 2001. Retrieved from: http://www.southsouthnorth.org

42. Tyner, W. The integration of energy and agricultural markets, Agric. Econ., 41, issue supplement s1, 2010, pp. 193-201.

43. Tyner, W.E., Taheripour, F. and Hurt Ch. Potential Impacts of a Partial Waiver of the Ethanol Blending Rules. Oak Brook, IL, Farm Foundation. 2012, pp. $1-13$.

44. UNEP. Green Economy: Metrics and Indicators, Briefing Paper, UNEP DTIE, Geneva. 2012.

45. Wright, B. Global Biofuels: Key to the Puzzle of Grain Behavior, J. Econ. Persp., 2014, no. 28(1), pp. 73-98.

46. Зарубинский В. Финансовое управление предприятием на основе использования открытой информации. Актуальні проблеми економіки. 2002. № 12. C. 31-41.

47. Зубкова А.В. Приемы антикризисного менеджмента (практическое пособие для бизнесменов и студентов). Ростов н/Д.: Феникс, 2008.

\section{References:}

1. Abbot, P. (2013). Biofuel, Binding Constrains and Agricultural Commodity Volatility, NBER Working Paper, 18873, pp. 1-46.

2. Allen, D., \& Berg, C. (2014). The sharing economy: How regulation could destroy an economic revolution, Institute of Public Affairs. Retrieved from: http://www.ipa.org.au

3. Artemov, A., Brykin, A., \& Shumaev, V. (2008). Modernization of the State Economic Management, Economist, no. 2, pp. 3-14.

4. Barua, P., Fransen, T., \& Wood, D. (2014). Climate Policy Implementation Tracking Framework. Working 5 Paper. Washington, DC: World Resources Institute. Retrieved from: http://wri.org/publication/climate6 policy-tracking

5. Bastia, F. (2017). Economic Harmonies. Selected. Moscow: Eksmo.

6. Bastow, S. (2013). Governance, Performance, and Capacity Stress: The Chronic Case of Prison Crowding. Basingstoke: Palgrave Macmillan. 
7. Carpenter, D., \& Moss, D. (2014). Preventing Regulatory Capture: Special Interest Influence and How to Limit It. NewYork: Cambridge UniversityPress.

8. Chupis, A. (1999). Financial Condition of Enterprise (Evaluation, Analysis, Planning): [Scientific and Teaching Edition]. Sumy: University Book.

9. De Gorter, H., Drabik, D, \&Just, D.R. (2013). Biofuel Policies and Food Grain Commodity Prices 2006-2012: All Boom and No Bust? AgBioForum, no. 16(1), pp. 1-13.

10. Fiore, E., \&Tamborrini, P., (2014). Open System in bean cultivation for Local Economical Development. Scientific Conference proceedings, Zilina (Slovakia), 9-13 June, pp. 359-364.

11. Herasym, P., Zhuravel, H., \& Khomyn, P. (2007). Course of Management Accounts. Kyiv: Znannia.

12. Herasymchuk, V. H. (1995). Diahnostyka systemy upravlinnia pidpryiemstvom. Kyiv: ISDO.

13. Hudz, O. (2009). Methodical Approaches to the Financial Diagnostics of Agricultural Entities, Collection of Scientific Works of Cherkasy State Technological University. Series "Economic Sciences": in 3 volumes. Cherkasy: ChDTU, 23. Vol. 1, pp. 9-14.

14. Khodakivska, O. V. (2013). Ecological Paradigm - the Basis of the Development of Economic Systems, Physical Economy In Terms of the Theory and Practice of Economic Activity: Collective Monograph / Ed. by Yu.O. Lupenko, V.V. Zhuk, V.O. Shevckuk and O.V. Khodakivska. Kyiv: NNTs "Institute of Agrarian Economy", pp. 226-227.

15. Hudz, O. Ie. (2012). Prohnozuvannia finansovoi stiikosti ta platospromozhnosti ahrarnykh pidpryiemstv. Zb. nauk. prats Umanskoho natsionalnoho universytetu sadivnytstva. Seriia «Ekonomichni nauky», 77. Ch. 2, pp. 119-125.

16. Imas, L., Morra, G., \& Ray, R. (2009). The Roads to Results: Designing and Conducting Effective 35 Development Evaluations. World Bank Publication.

17. Kaletnik, H. M. (2015). Vyrobnytstvo ta vykorystannia biopalyv. Vinnytsia: Konsol.

18. Kamel, S., \& Dahl, C. (2004). The economics of hybrid power systems for sustainable desert agriculture in Egypt. Energy (2004, forthcoming), Elsevier.

19. Korpaniuk, T. M. (2016). Financial and Economic Diagnostics of Agricultural Enterprises Engaged in Biofuel Production, Economics. Finance. Management: Topical Issues of Science and Practice, no. 12, pp. 63-70.

20. Korpaniuk, T. M. (2016). Informational and Analytical Provision of Financial and Economic Diagnistics in Agricultural Enterprises. Bulletin of the Odesa National University. Series: Economics, vol. 21, is. 5, pp. 83-86.

21. Maliuha, N. (1998). Ways of improving Evaluation in Accounting: Theory, Practice and Prospects. Zhytomyr: XhiTI, pp. 384.

22. McPhail, L. L., \& Babcock, B. A. (2012). Impact of US biofuel policy on US corn and gasoline price variability, Energy, 37, issue 1, pp. 505-513.

23. Moschini, G., Cui, J., \& Lapan, H. (2012). Economics of Biofuels: An Overview of Policies, Impacts and Prospects, Economics Publications, 96. Retrieved from: http://lib.dr.iastate.edu/econ_las_pubs/96 
24. Nilsson, M., et al. (2016). Policy: Map the interactions between Sustainable Development Goals, Nature, 18. Retrieved from: http://www.nature.com/news/policy-map-the-interactions-between-sustainable-development19 goals-1.20075

25. OECD (2012). Background Report for the OECD Strategy on Development, C(2012)61/REV1, OECD, Paris.

26. Oxford Business English Dictionary. Retrieved from: http://askoxford.com/ conciseoed/rating? view $=$ uk

27. Pravdiuk, N. (2005). Trends of the development of Financial Accounting in Agroindustrial Production: [Monograph]. Kyiv: NNTs "Institute of Agrarian Economy".

28. Pruts'ka, O. O. (2010). Derzhavne reguljuvannja rozvytku rynku biopalyva v Ukrai'ni. Visnyk Zaporiz'kogo nacional'nogo universytetu, no. 1(5), pp. 179-182.

29. Report of the International Ministerial Conference of Landlocked and Transit Developing Countries and Donor Countries and International Financial and Development Institutions on Transit Transport Cooperation, Almaty, Kazakhstan, 28 and 29 August 2003 (A/CONF.202/3), annex I.

30. Romer, Paul M. (1999). Endogenous Technological Change, Levine's Working Paper Archive, 2135.

31. Samoilenko, A. H. (2009). Otsinka potentsialu ahrarnoi syrovynnoi bazy dlia vyrobnytstva biopalyva. Ekonomika ta pidpryiemnytstvo: zb. nauk. prats molo$d y k h$ uchenykh ta aspirantiv, no. 22, pp. 177-184.

32. Savchuk, V. P. (2001). Fynansovj menedzhment predpryyatyj: prykladne voprosu s analyzom delovux sytuacyj. Kyiv: Yzdatelskyjdom "Maksy' mum".

33. Skibitskyi, O.M. (2009). Anticrisis Management. Kyiv: Ceter of Academic Books.

34. Strategy of Environmental Security of Ukraine in the Context of International Experience (2008). Department for Integration and Strategic Partnership. Retrieved from: http://old.niss.gov.ua/Monitor/Juli08/21.htm

35. Shevchenko, V. (2018). The Use of Energy Saving Technology in the EU countries: Experience for Ukraine. Analytical Note, National Institute for Strategic Studies. Retrieved from: http://www.niss.gov.ua/articles/262/

36. Shcherbak, A. (2008). Prospects of the use of Ranking Scores in the Investment Activity of Enterprises. Economy and Management of the Enterprise, no. 5(83), pp. 83-91.

37. Shvydanenko, H. O. (2002). Suchasna tekhnolohiia diahnostyky finansovo-ekonomichnoi diialnosti pidpryiemstva: monohrafiia. Kyiv: KNEU.

38. Sokolovskaia, Z. N. (1995). Dyahnostyka khoziaistvennykh sytuatsyi v deiatelnosty predpryiatyia: monohrafyia. Odessa: OTsNT; OKFA.

39. Srebotnjak, T., Polzin, C., Giljum, S., Herbert, S., \& Lutter, S. (2010). Establishing Environmental Sustainability Thresholds and Indicators: Final report. Brussels: Ecologic Institute and SERI.

40. Tsal-Tsalko, Yu. (2001). Financial Reporting of the Enterprise and its Ananlyisis - 2-nd ed., as amended. Zhytomyr.

41. Thorne, S., \& Raubenheimer, S. (2001). Sustainable Development (SD) appraisal of Clean Development Mechanism (CDM) projects - experiences from the South South North (SSN) project. Retrieved from: http://www. southsouthnorth.org 
42. Tyner, W. (2010). The integration of energy and agricultural markets, Agric. Econ., 41, issue supplement s1, pp. 193-201.

43. Tyner, W. E., Taheripour, F., \& Hurt Ch. (2012). Potential Impacts of a Partial Waiver of the Ethanol Blending Rules, OakBrook, IL, Farm Foundation, pp. 1-13.

44. UNEP (2012). Green Economy: Metrics and Indicators, Briefing Paper, UNEP DTIE, Geneva.

45. Wright, B. (2014). Global Biofuels: Key to the Puzzle of Grain Behavior, J. Econ. Persp., no. 28(1), pp. 73-98.

46. Zarubynskyi, V. (2002). Financial Management of the Enterprise based on the Use of Open Information, Topical Problems of Economics, no. 12, pp. 31-41.

47. Zubkova, A. V. (2008). Anticrisis Management Techniques (Prectical Manual for Businessmen and Students). Rostov on Don: Feniks. 